\title{
KAMU VE ÖZEL KURUMLARA BAŞVURAN HASTALARDA JINEKOLOJIK MUAYENEYE BAĞLI DURUMLUK ANKSIYETENIN KARŞILAŞTIRILMASI
}

\author{
Ayşe DEMIRAY ${ }^{3}$, Esra AKIN KORHAN ${ }^{4}$, Kıvan ÇEVIK ${ }^{5}$, Leyla KHORSHID ${ }^{6}$, Mehmet Sait YÜCEBiLGiN7
}

\begin{abstract}
ÖZET
Amaç: Bu tanımlayıcı çalışma bir kamu ve özel kuruma jinekolojik muayene için başvuran hastaların jinekolojik muayeneye bağlı durumluk anksiyete düzeyini karşılaştırmak amacıyla yapılmıştır.

Yöntem: Çalışma 1 Şubat 2012-30 Mart 2012 tarihleri arasında bir devlet hastanesi ve özel bir kurumun jinekoloji polikliniğinde yürütülmüştür. Örneklem $(n=60)$ gebe olmayan, 18-49 yaş grubundaki ve jinekolojik bir yakınma nedeniyle polikliniğe başvuran kadın hastalardan oluşmuştur. Verilerin toplanmasında araştırmacılar tarafından geliştirilen bir anket formu ve Durumluk Anksiyete Ölçeği kullanılmıştır. Anket formu ve Durumluk Anksiyete Ölçeği hastalara jinekolojik muayeneden önce uygulanmıştır. Verilerin analizi SPSS 16.0 programında yapılmıştır. Verilerin analizinde Fisher's exact test, Paired-sample t test, The Mann-Whitney ve Kruskal-Wallis test kullanılmıştır.

Bulgular: Hastaların \%80'i 5 ve daha fazla kez jinekolojik muayene olmuştu ve \%71.7'si yalnız jinekolojik bir yakınması olduğunda veya gebe kaldığında bir jinekoloji kliniğine başvurduğunu, \%28.3'ü her altı ayda bir düzenli olarak jinekoloji kliniğine gittiğini, \%21.7'si jinekolojik muayene sırasında utandığını belirtmiştir. Jinekolojik muayeneye bağlı durumluk anksiyete puan ortalaması $39.41 \pm 4.86$.olarak bulunmuştur.

Sonuç: Kamu ve özel kurumlara jinekolojik muayeneye başvuran hastalarda jinekolojik muayeneye bağlı durumluk anksiyete puan ortalamaları arasında anlamlı bir fark bulunmamıştır. Her iki kuruma jinekolojik muayeneye başvuran hastalar jinekolojik muayeneye bağlı orta düzeyde durumluk anksiyete
\end{abstract} deneyimlemektedirler.

Anahtar sözcükler: jinekolojik muayene; anksiyete; kadınlar

\section{A Comparison Of The State Anxiety Related To Gynecological Examination In Patients Attended In Public And} Private Institution

\begin{abstract}
Aim: This descriptive study was conducted with the aim of comparing the state anxiety related to gynecological examination in patients attended to gynecological examination in public and private institution.

Methods: The study was conducted between February 1, 2012 and March 30, 2012 in the gynecological outpatient department of a public hospital and a private institution. The sample $(n=60)$ consisted of female patients who were not pregnant and aged between 18 and 49 who attended the outpatient clinic for gynecological examination with a gynecological complaint. A questionnaire developed by the researchers and consisting of two parts and the State Anxiety Inventory Form (STAI) were used to collect data. The questionnaire and State-Trait Anxiety Inventory Form (STAI) was applied to the patients before gynecological examination. Statistical analyses were undertaken using SPSS for Windows Version 16.0. In analysis of the data Fisher's exact test, Paired-sample t test, The Mann-Whitney and the Kruskal-Wallis test were used.

Findings: Overall, $80 \%$ had previously undergone 5 or more gynecological examinations, $71.7 \%$ reported that they attended a gynecological clinic only when they had gynecological symptoms or had being pregnant, $28.3 \%$ of them stated that they gynecological attended a clinic for routine assessment every 6 months, and $21.7 \%$ of the women felt embarrassed about gynecological examination. Mean trait anxiety score due to gynecological examination was found to be $39.41 \pm 4.86$. The mean state anxiety scores were similar for the patients in the different age groups, education level, marital status.

Conclusion: No significant difference in mean state anxiety scores was found before gynecological examination between woman attended to for gynecological examination in public and private institution. Patients experience state anxiety at a mild level due to gynecological examination in both private and outpatient clinics.

Key words: gynecological examination; anxiety;women
\end{abstract}

\footnotetext{
${ }^{3} Y r d$. Doç. Dr, Düzce Üniversitesi Sağlık Yüksekokulu Hemşirelik Bölümü, aysedemiray@duzce.edu.tr

${ }^{4}$ Doç. Dr, İzmir Katip Çelebi Üniversitesi, Sağlık Bilimleri Enstitüsü, Hemşirelik Bölümü, akinesra80@hotmail.com

${ }^{5}$ Yrd. Doç. Dr, Celal Bayar Üniversitesi, Manisa Sağlık Yüksekokulu, Hemşirelik Bölümü, kivancevik@hotmail.com

${ }^{6}$ Prof. Dr., Ege Üniversitesi, Hemşirelik Fakültesi, leyla.khorshid@yahoo.com

7Prof. Dr., Ege Üniversitesi, Tıp Fakültesi, Kadın ve Doğum Hastalıkları Anabilim Dalı,syucebilgin@yahoo.com
} 


\section{GiRiş}

Jinekolojik muayene, sağlığın korunması için düzenli olarak (Mete 1998) yapılması gereken ve sık kullanılan bir uygulamadır (Larsen, Oldeide and Malterud 1997). Düzenli jinekolojik muayene ile yapılan kontroller, cinsel yolla bulaşan enfeksiyonların, genital kanserlerin ve diğer sağlık sorunların erken dönemde teşhisini sağlayarak kadın sağlığının korunmasında çok önemli bir yere sahiptir. Diğer doku-organ sistemlerinin tıbbi muayenelerinden çok farklı olarak, jinekolojik muayene hasta ve doktor için de olumsuz bilişsel, davranışsal durumları bünyesinde barındırmaktadır (Aksakal 2001).

Kadınların çoğu, çok küçük bir kız olduğu dönemden başlayıp bütün yaşamı boyunca örtmesi, saklaması, gizlemesi, koruması gereken genital organlarının muayenesi sırasında hafif anksiyete ve utanma hissinden muayene olmaktan kaçınmaya kadar değişen reaksiyonlarla sonuçlanmış travmatize etki yaşar (Millstein, Adler and Irwin 1984). Yapılan araştırmalarda, jinekolojik muayenede yaşanan anksiyetenin; sağlık personelinin olumsuz tutumu, muayene eden sağıı personelinin karşı cinsten olması, muayene pozisyonu, kullanılan aletler, önceki olumsuz muayene deneyimleri, mahremiyete dikkat edilmemesi, ağrı korkusu, patolojik tanı konulma korkusu, kişisel temizlik hakkında korku, genital bölgenin çıplak olması nedeniyle utanma, cinselliğin olumsuz algılanması, genç yaşta olma, muayene deneyiminin olmaması gibi nedenleri olduğu belirlenmiştir (Aksakal 2001; Frye and Weisberg 1994; Hilden, Sidenius, Langhoff and Wijma 2003; Larsen, Oldeide and Malterud 1997; Millstein, Adler and Irwin 1984). Sert, aceleci, duyarsız ve hasta ile sözel iletişime girmeden yapılan jinekolojik muayenelerin ise, kadınlarda utanma duygusunun ve korkusunun artmasına neden olduğu literatürde belirtilmektedir (Taşkın 2005). Yapılan bir çalışmada, jinekolojik muayene sırasında kadınların \%62,5'i utanma, \% 38,8'i sıkıntı, \%37,9'u korku ve \%21,7'si ağrı yaşadığını ifade etmiştir (Erbil, Şenkul, Sağlam ve Ergül 2008). Özel bir kuruma jinekolojik muayene için başvuran 525 kadınla yapılan bir çalışmada, her dört hastadan birinde elleri tutma, gözleri kapatma, elleri omuzların üzerine koyma, pelvisi ellerle kapatma, elleri bacakların üzerine koyma, ellerle masayı tutma olmak üzere jinekolojik muayene sırasındaki anksiyeteyi gösteren 5 davranış belirlenmiştir (Reddy and Wasserman 1997).

Jinekolojik muayene deneyiminin olumsuz olması, kadını bundan sonraki muayenelere gelmekten alıkoyabilir (Hilden, Sidenius, Langhoff and Wijma 2003) ve düzenli jinekolojik kontrollerle amaçlanan kadın sağlığını korumak mümkün olamayabilir. Ülkemizde kamu kurumlarına olan yoğun hasta başvurusu nedeniyle her hastaya ayrılması gereken sürenin az olması jinekolojik muayeneye bağı anksiyeteyi arttıran etmenlere zemin hazırlamaktadır. Ayrıca jinekolojik muayene için kadın hekime muayene olma isteği nedeniyle kadınlar jinekolojik muayene için özel poliklinikleri tercih etmektedir._ülkemizde özel ve kamu hastanelerinde jinekolojik muayene olan kadınların durumluk anksiyetelerini karşılaştıran bir çalışmaya erişilememiştir. Bu araştırma sonuçlarının, kadınların jinekolojik muayene sırasında yaşadıkları anksiyete kaynaklarından birinin incelenerek, bunun azaltılmasına yönelik çalışmalara zemin oluşturacağı düşünülmektedir.

\section{AMAÇ}

Bu çalışma, özel ve kamu kurumunda jinekolojik muayeneye başvuran kadınların durumluk anksiyete düzeyini karşılaştırmak amacıyla tanımlayıcı olarak yapılmıştır.

\section{GEREÇ VE YÖNTEM}

Tanımlayıcı türdeki bu araştırmanın evrenini, Manisa Devlet Hastanesi'ne bağlı Doğum ve Çocuk Bakımevi Hastanesi Jinekoloji Polikliniğine ve özel bir muayenehaneye jinekolojik muayene için başvuran 15 yaş ve üzeri grubundaki kadın hastalar oluşturmuştur. Araştırmanın örneklemini, olasılıksız örnekleme tekniği ile seçilen, 1 Şubat 2012-30 Mart 2012 tarihleri arasında Manisa Devlet Hastanesi'ne bağlı Doğum ve Çocuk Bakımevi Hastanesi Jinekoloji Polikliniğine ve özel bir muayenehaneye jinekolojik muayene için başvuran 15 ve üzeri yaş grubundaki kadın hastalar oluşturmuştur. Her iki gruptaki kadınlar yaş grubu açısından eşitlenmiştir.

Araştırma verilerinin toplanmasında Hasta Tanıtım Formu ve Spielberger tarafından 1973 yılında geliştirilen ve ülkemizde 1977 yılında Öner tarafından geçerlik ve güvenirlik çalışmaları gerçekleştirilen Durumluk Anksiyete Ölçeği (Öner ve LaCompte 1983) kullanılmıştır. Hasta Tanıtım Formunda hastaların yaşı, cinsiyeti, jinekolojik muayene öyküsü ve jinekolojik muayeneye ilişkin görüş ve hissettiği duygulara ilişkin sorular yer almıştır. Durumluluk Anksiyete Ölçeği 20 sorudan oluşmaktadır ve cevap seçenekleri 4' er tanedir. Seçeneklerin ağırlık değerleri 1'den 4'e kadar değişmektedir. Ölçek 20 ifadeden oluşmaktadır ve ölçekten elde edilen toplam puan değeri 20 ila 80 puan arasında değişmektedir. Puanın yüksek olması kaygı seviyesinin yüksek olduğunu göstermektedir. Bu çalışmada durumluk anksiyete ölçeğinin güvenirlik katsayısı Cronbach Alpha $=0.88$ olarak bulunmuştur.

Araştırma verileri, 1 Şubat 2012-30 Mart 2012 tarihleri arasında toplanmıştır. Araştırma, Manisa Devlet Hastanesi'ne bağı Doğum ve Çocuk Bakımevi Hastanesi Jinekoloji Polikliniğinde ve özel bir muayenehanede, jinekolojik muayene için başvuran 15 yaş ve üzeri grubundaki kadın hastalar ile gerçekleştirilmiştir. 
Araştırmaya 15 yaş ve üzeri, 49 yaşın altında, okuma yazma bilen, gebe olmayan kanser tanısı almamış olan, nörolojik ve psikiyatrik tanısı almamış olan, herhangi bir nedenle sedatif veya trankilizan ilaç almayan, bilinci açık, sözel iletişim kurabilen, işitme problemi ve jinekolojik muayene olmak üzere başvuran ve araştırmaya katılmayı kabul eden kadınlar alınmıştır. Anket formları bir araştırmacı tarafından kadınlara muayeneden önce, bekleme odasında uygulanmıştır Anket sorularından elde edilen veriler bilgisayar ortamında SPSS 16.0 programında kodlanıp sayı-yüzde dağılımları elde edilerek değerlendirilmiştir. Verilerin analizinde kikare, t testi, Mann-Whitney U ve Kruskall Wallis testi kullanılmıştır.

Araştırma etik ilkelere uygun olarak yürütülmüştür. Ege Üniversitesi Hemşirelik Fakültesi Etik Kurulu'ndan onay alınmıştır. Manisa Devlet Hastanesi'ne bağlı Doğum ve Çocuk Bakımevi Hastanesi Jinekoloji Polikliniğinde ve özel muayenehaneden araştırmanın yürütülmesi için gerekli yazılı izin alınmıştır. Araştırmaya katılmak isteyen hastaların sözel onamları alınmıştır.

\section{BULGULAR VE TARTIŞMA}

Tablo 1. Kadınların Tanıtıcı Özelliklerine Göre Dağılımı

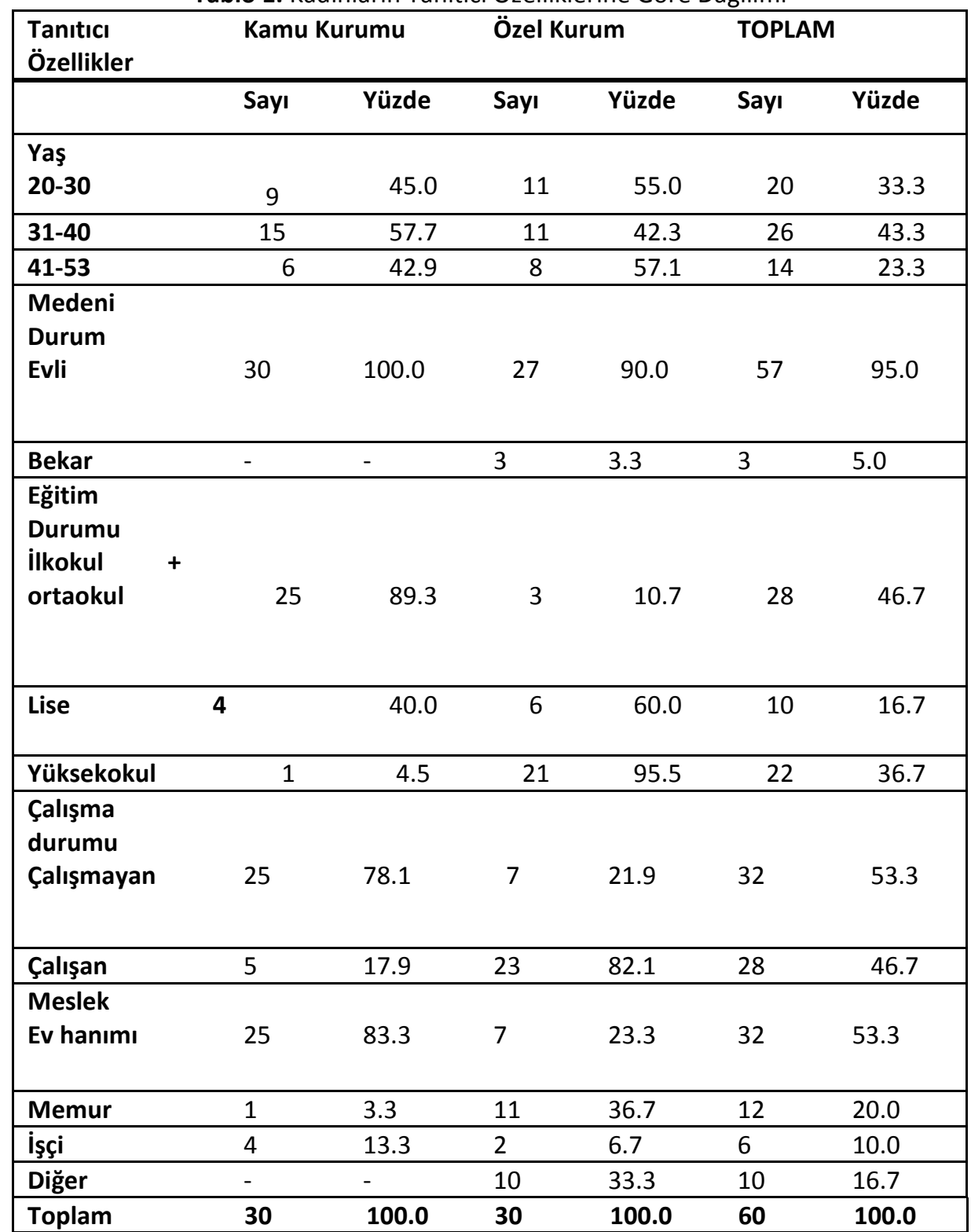

Kadınların \%43.3'ü 31-40 yaş grubundadır, \%95'i evlidir, \%46.7' si ilköğretim mezunudur, \%53.3'ü bir işte çalışmamaktadır (Tablo 1). Yaş ortalaması $34.75 \pm 7.94$ yıl (min:20, max: 53) olarak bulunmuştur. 
Tablo 2. Kadınların Muayene Olduğu Sağlık Kuruluşuna Göre Dağılımı

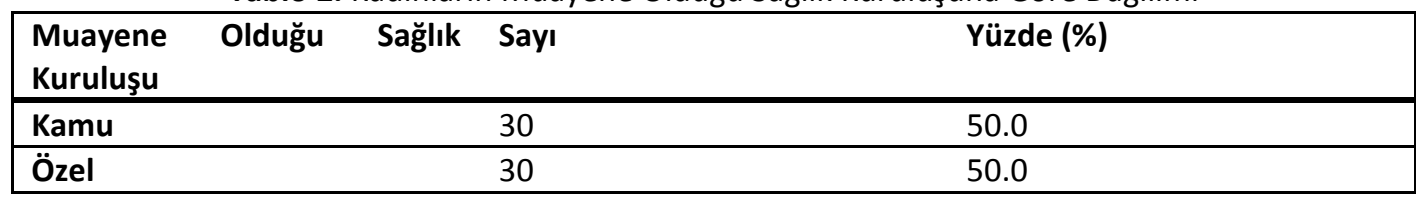

Kadınların \%50’si bir kamu kuruluşunda, \%50’si özel bir kurumda jinekolojik muayene olmuştur (Tablo 2).

Tablo 3. Kadınların Jinekolojik Muayene Özelliklerine ve Muayene ile İlgili Görüşlerine Göre Dağılımı

\begin{tabular}{|c|c|c|c|c|c|c|}
\hline \multirow[t]{2}{*}{ Özellikler } & \multicolumn{2}{|c|}{ Kamu Kurumu } & \multicolumn{2}{|c|}{ Özel Kurum } & \multicolumn{2}{|c|}{ TOPLAM } \\
\hline & Sayı & Yüzde & Sayı & Sayı & Yüzde & Sayı \\
\hline \multicolumn{7}{|l|}{ Jinekolojik muayene sayısı } \\
\hline 1 & 6 & 20.0 & 2 & 6.7 & 8 & 13.3 \\
\hline $2-4$ & 4 & 13.3 & - & - & 4 & 6.7 \\
\hline 5 ve üzeri & 20 & 66.7 & 28 & 93.3 & 48 & 80.0 \\
\hline \multicolumn{7}{|l|}{$\begin{array}{l}\text { Jinekolojik muayeneye gittiği } \\
\text { durumlar }\end{array}$} \\
\hline Her altı ayda bir düzenli gelirim & 4 & 13.3 & 13 & 43.3 & 17 & 28.3 \\
\hline $\begin{array}{l}\text { Mümkün olduğunca gelmemeye } \\
\text { çalıșırım }\end{array}$ & 2 & 6.7 & 6 & 20.0 & 8 & 13.3 \\
\hline Ancak çok acil bir rahatsızlığım & & & & & & \\
\hline olduğunda gelirim & 23 & 76.7 & 5 & 16.7 & 28 & 46.7 \\
\hline Sadece hamile kaldığımda gelirim & 1 & 3.3 & 6 & 20.0 & 7 & 11.7 \\
\hline \multicolumn{7}{|l|}{$\begin{array}{l}\text { Jinekolojik muayeneye düzenli olarak } \\
\text { gelmeyi engelleyen nedenler } \\
\text { Yanıtsız }\end{array}$} \\
\hline Maddi yetersizlikler & 12 & 40.0 & 14 & 47.6 & 36 & 60.0 \\
\hline Muayene şeklinin zorluğu & - & - & 1 & 3.3 & 1 & 1.7 \\
\hline $\begin{array}{l}\text { Muayenede } \quad \text { kendimi } \quad \text { rahat } \\
\text { hissetmemek }\end{array}$ & 8 & 26.6 & 4 & 13.3 & 12 & 20.0 \\
\hline İş yoğunluğu & 3 & 10.0 & 3 & 10.0 & 6 & 10.0 \\
\hline Muayeneye bağlı korku & 1 & 3.3 & 2 & 6.7 & 3 & 5.0 \\
\hline & 1 & 3.3 & 1 & 3.3 & 2 & 3.3 \\
\hline $\begin{array}{l}\text { Muayene sırasında hemşireden } \\
\text { beklentiler }\end{array}$ & & & & & & \\
\hline Yanıtsız & - & - & 8 & 26.6 & 8 & 13.3 \\
\hline Nazik olması & 8 & 26.6 & 5 & 16.6 & 13 & 21.7 \\
\hline Beklentim yok & 1 & 3.3 & 1 & 3.3 & 2 & 3.3 \\
\hline Samimi ve içten olması & 7 & 23.3 & 2 & 6.6 & 9 & 15.0 \\
\hline Görevini yerine getirmesi & - & - & 10 & 33.3 & 10 & 16.7 \\
\hline $\begin{array}{l}\text { Güleryüzlü, bilgili, güven verici, temiz } \\
\text { olması }\end{array}$ & 5 & 16.6 & 7 & 23.3 & 12 & 20.0 \\
\hline Yardımcı, ilgili olması & - & - & 5 & 16.6 & 5 & 8.3 \\
\hline Mahremiyete özen göstermesi & - & - & 1 & 3.3 & 1 & 1.7 \\
\hline $\begin{array}{l}\text { Muayene sırasında } \quad \text { hekimden } \\
\text { beklentiler }\end{array}$ & & & & & & \\
\hline Beklentisi olmayan & 5 & 16.7 & 1 & 3.3 & 6 & 10.0 \\
\hline Aydınlatıcı, kibar, temiz & 1 & 3.3 & 8 & 26.7 & 9 & 15.0 \\
\hline Güven verici & 1 & 3.3 & 5 & 16.7 & 6 & 10.0 \\
\hline Konusunda uzman ve güvenilir & 3 & 10.0 & 10 & 33.3 & 13 & 21.7 \\
\hline Güleryüzlü ve açık & 2 & 6.7 & 6 & 20.0 & 8 & 13.3 \\
\hline İlgili & 6 & 20.0 & - & - & 6 & 10.0 \\
\hline Bayan olması & 12 & 40.0 & - & - & 12 & 20.0 \\
\hline
\end{tabular}




\begin{tabular}{|lllllll|}
\hline $\begin{array}{l}\text { Jinekolojik muayene ile ilgili hissettiği } \\
\text { duygular }\end{array}$ & & & & & & \\
Herhangi bir duygu hissetmeyen & 2 & 6.7 & 5 & 16.7 & 7 & 11.6 \\
Tedirginlik & 3 & 10.0 & 6 & 20.0 & 9 & 15.0 \\
Kaçma isteği & 3 & 10.0 & 1 & 3.3. & 4 & 6.7 \\
Korku & 4 & 13.3 & 4 & 13.3 & 8 & 13.3 \\
Heyecan & 3 & 10.0 & 3 & 10.0 & 6 & 10.0 \\
Utanma & 9 & 30.0. & 4 & 13.3 & 13 & 21.7 \\
Sıkıntı & 6 & 20.0 & 7 & 21.6 & 13 & 21.7 \\
\hline Muayene eden hekimin cinsiyeti & & & & & & \\
Kadın & 24 & 80.0 & - & - & 24 & 40.0 \\
Erkek & 6 & 20.0 & 30 & 100.0 & 36 & 60.0 \\
\hline TOPLAM & 30 & 100.0 & 30 & 100.0 & 60 & 100.0 \\
\hline
\end{tabular}

Kadınların jinekolojik muayeneye bağlı durumluk anksiyete puan ortalaması $39.41 \pm 4.86$ (min:29, max: 52) olarak bulunmuştur ( $s=60)$.

Kadınların yaklaşık 1/3'ü (\%28.3'ü) düzenli olarak jinekolojik muayeneye gittiklerini, diğerleri ise bir yakınması olduğunda veya gebe kaldığında jinekolojik muayeneye gittiklerini belirtmiştir. Kadınların \%40'ı maddi yetersizlikler, iş yoğunluğu, muayene şeklinin zorluğu, muayenede kendini rahat hissetmediği, veya muayeneye bağlı korku nedeniyle jinekolojik muayeneye düzenli olarak gitmediğini belirtmiştir (Tablo 3).

$\mathrm{Bu}$ sonuç, jinekolojik muayeneye bağlı hissedilen duyguların bireyleri düzenli jinekolojik kontrollere gitmelerini engellediğini düşündürmektedir. Kocabaş ve Khorshid (2012)' in çalışmasında kadınların \%67.8'i yalnızca jinekolojik bir yakınması olduğunda, \%22.2' i ise 6 ayda bir düzenli olarak jinekolojik muayeneye gittiklerini belirtmiştir. Çalışma sonuçlarımız, Yanıkkerem, Özdemir, Bingöl, Tatar ve Karadeniz (2009) ile Kocabaş ve Khorshid (2012)'in çalışma sonuçları ile paralellik göstermektedir.

Jinekolojik muayene jinekolojik bakımın temel bir bölümüdür ve çoğu kadın yaşamları boyunca bu işlemi birkaç kez deneyimler (Hilden, Sidenius, Langhoff and Wijma 2003; Oscarsson, Benzein and Wijma 2007; Yanıkkerem, Özdemir, Bingöl, Tatar ve Karadeniz 2009). Çalışmada kadınların büyük çoğunluğu (\%80) 5 ve daha fazla sayıda jinekolojik muayene deneyimlediklerini belirtmiştir. Muayene deneyimi sayısı arttıkça, jinekolojik muayeneye bağlı anksiyetenin azalacağı düşünülmüştür.

Jinekolojik muayene anksiyeteye yol açan yaygın tıbbi işlemlerden biridir (McCarthy 1997), sıkıntı ve rahatsızlığa neden olur (Haar, Halitsky and Srick 1977; Yanıkkerem, Özdemir, Bingöl, Tatar ve Karadeniz 2009). Bu muayene bazı kadınlar tarafından itici olarak algılanabilir (Hilden, Sidenius, Langhoff and Wijma 2003). Jinekolojik muayene güvensizlik ve çaresizlik duygularına neden olabilir (McCarthy 1997). Pelvik muayene duyarlı bir tıbbi işlemdir, etik ve etkileşim konusunda yeterli standartları sağlamak için kalite güvencesine gereksinim bulunmaktadır (Larsen, Oldeide and Malterud 1997). Kadınların jinekolojik muayene deneyimlerini saptamak amacıyla yapılan kalitatif bir çalışmada, kadınların jinekolojik muayeneden önce sinirli oldukları, ancak hastalıklardan korunmak için muayene oldukları belirlenmiştir (Larsen, Oldeide and Malterud 1997). Kadınların jinekolojik muayeneden önce neler deneyimlediklerini ve yaşanan bu sıkıntıya eşlik eden etmenleri belirlemek amacıyla yapılan bir çalışmada, jinekolojik muayene sırasında yaşanan sıkıntının genç yaş grubuyla ve olumsuz duygularla ilişkili olduğu sonucuna varılmıştır (Hilden, Sidenius, Langhoff and Wijma 2003). Erbil, Şenkul, Sağlam ve Ergül (2008)'ün çalışmasında kadınların jinekolojik muayene sırasında utanma (62.5\%), sıkıntı, (38.8\%), korku (37.9\%) ve ağrı (21.7\%) algıladıkları saptanmıştır. Kocabaş ve Khorshid (2012)'in araştırmasında kadınların \%64.4'ünün jinekolojik muayenede giysilerini çıkarma nedeniyle utandıklarını belirtmiştir. Yanıkkerem, Özdemir, Bingöl, Tatar ve Karadeniz (2007)'in bir jinekoloji polikliniğinde 433 kadınla yaptıkları bir çalışmada, kadınların yarıdan fazlasının jinekolojik muayene sırasında kendi sağlık durumları hakkında endişelendiklerini (\%54.8), \%41.8'inin giysilerini çıkardıkları için utandıklarını belirtmiştir. Çalışmamızda kadınların \%15’i jinekolojik muayene sırasında tedirginlik, \%13.3’ü korku, \%21.7' si utanma ve sıkıntı hissettiklerini belirtmiştir. Bu sonuçlar literatür bilgilerini doğrulayıcı niteliktedir.

Kadınların yaklaşık 1/5’i jinekolojik muayene sırasında hemşireden "nazik" (\%21.7), "güleryüzlü, bilgili, güven verici temiz" (\%20) olmasını, \%21.7'si ise jinekolojik muayene sırasında hekimden "konusunda uzman ve güvenilir" olmasını beklediklerini belirtmiştir (Tablo 2). Erbil, Şenkul, Sağlam ve Ergül (2008)'ün çalışmasında "hekimin bilgisinin ve yeteneğinin" (63.8\%) ve "hoşgörülü olmanın" (41.7\%) kadınların jinekolojik muayene için hekim seçmesinde etkili etmenler olarak bulunmuştur. Çalışma sonuçlarımız literatür bilgilerini desteklemektedir. 
Tablo 4. Kadınların Tanıtıcı Özelliklerine Göre Anksiyete Puan Ortalamalarının Karşılaştırılması

\begin{tabular}{|c|c|c|c|}
\hline Etmenler & s & Ortalama (SD) & Anlamlılık \\
\hline \multicolumn{4}{|l|}{ Yaş grubu } \\
\hline 20-30 yaş grubu & 20 & $38.60 \pm 3.93$ & $K W x^{2}=1.465$ \\
\hline $31-40$ yaş grubu & 26 & $40.15+5.21$ & $p=0,481$ \\
\hline $41-53$ yaş grubu & 14 & $39.21 \pm 5.52$ & \\
\hline \multicolumn{4}{|l|}{ Eğitim düzeyi } \\
\hline ilkokul +ortaokul & 28 & $40.64+4.41$ & $K W x^{2}=5.63$ \\
\hline Lise & 10 & $38.00 \pm 4.61$ & $p=0.060$ \\
\hline Yüksekokul & 22 & $38.50 \pm 5.34$ & \\
\hline Medeni Durum & & & $U=56.5$ \\
\hline Evli & 57 & $39.52 \pm 4.93$ & $p=0.342$ \\
\hline Bekar & 3 & $37.33 \pm 3.05$ & \\
\hline Bir işte çalışma & & & $U=330.5$ \\
\hline Çalışmayan & 32 & $40.31 \pm 4.80$ & $p=0.081$ \\
\hline Çalışan & 28 & $38.39+4.86$ & \\
\hline \multicolumn{4}{|l|}{ Meslek } \\
\hline Ev hanımı & 32 & $40.31 \pm 4.80$ & $x^{2}=6.150$ \\
\hline Memur & 12 & $35.50 \pm 3.70$ & \\
\hline İşçi & 6 & $40.00 \pm 2.28$ & $p=0.105$ \\
\hline Diğer & 10 & $39.70 \pm 6.44$ & \\
\hline \multicolumn{4}{|l|}{ Muayene olduğu sağlık kuruluşu } \\
\hline Kamu & 30 & $40.40 \pm 4.84$ & $\mathrm{t}=1.584$ \\
\hline Özel & 30 & $38.43+4.76$ & $p=0.119$ \\
\hline \multicolumn{4}{|l|}{ Jinekolojik muayene sayısı } \\
\hline ilk & 8 & $40.00+5.90$ & $\mathrm{KW} \mathrm{x}^{2}=0.977$ \\
\hline 2-4 & 4 & $39.00 \pm 5.35$ & $P=0.614$ \\
\hline-5 ve üstü & 48 & $39.02 \pm 4.62$ & \\
\hline \multicolumn{4}{|l|}{ Jinekolojik muayene yapan hekimin cinsiyeti } \\
\hline Kadın & 24 & $40.62 \pm 5.25$ & $U=309.5$ \\
\hline Erkek & 36 & $38.61 \pm 4.48$ & $p=0.064$ \\
\hline \multicolumn{4}{|l|}{ Jinekolojik muayeneye gittiği durumlar } \\
\hline Her altı ayda bir düzenli giden & 17 & $38.41 \pm 5.67$ & $U=297$ \\
\hline Yalnızca yakınması ya da gebe olduğunda giden & 43 & $39.81 \pm 4.52$ & $p=0.260$ \\
\hline \multicolumn{4}{|l|}{$\begin{array}{l}\text { Jinekolojik muayene ile ilgili hissettiği duygular } \\
\text { Herhangi bir duygu hissetmeyen }\end{array}$} \\
\hline \multirow[t]{2}{*}{ Olumsuz duygular hisseden } & 7 & $37.85 \pm 3.23$ & $U=140$ \\
\hline & 53 & $39.62+4.86$ & $p=0.307$ \\
\hline
\end{tabular}

Kadınların yaş grubunun, eğitim düzeyinin, medeni durumunun, bir işte çalışmasının, mesleğinin, başvurduğu kurumun, jinekolojik muayene sayısının, jinekolojik muayene yapan hekimin cinsiyeti, jinekolojik muayeneye gittiği, jinekolojik muayene ile ilgili hissettiği duyguların jinekolojik muayeneye bağlı anksiyetelerini etkilemediği saptanmıştır (Tablo 4).

Durumluk anksiyete ölçeği 20 ifadeden oluşmaktadır ve ölçekten elde edilen toplam puan değeri 20 ila 80 puan arasında değişmektedir. Puanın yüksek olması kaygı seviyesinin yüksek olduğunu göstermektedir. Ayrıca ölçekten alınan 0-19 puan "anksiyete yok", 20-39 puan "hafif anksiyete", 40-59 puan "orta anksiyete", 60-79 puan "ağır anksiyete" ve 80 puan çok şiddetli panik olarak sınıflandırılmaktadır. Kadınların jinekolojik muayeneye bağlı durumluk anksiyete puan ortalaması $39.41 \pm 4.86$ (min:29, max: 52) olarak bulunmuştur $(s=60)$. Bu sonuç kadınların jinekolojik muayene sırasında orta düzeyde anksiyete deneyimlediklerini göstermektedir. Bu sonuç kadınların büyük çoğunluğunun (\%80) 5 ve daha fazla sayıda jinekolojik muayene deneyimlemelerine bağlanabilir. Kocabaş ve Khorshid (2012)'in çalışmasında kontrol grubundaki hastaların muayeneden önce durumluk anksiyete düzeyi 49.40 olarak bulunmuştur. Erbil, Şenkul, Sağlam ve Ergül (2008)'ün 240 kadın hastada yaptığı bir çalışmada, jinekolojik muayeneden önce durumluk anksiyete puan 
ortalamasının 43.85£5.41 olduğu ve orta düzeyde anksiyete deneyimledikleri saptanmıştır. Yarıcı, Oflaz, Arslan, Gürsoy, Özbay, Gezginci, et al. (2009) çalışmasında kadın hastaların jinekolojik muayeneden önce orta düzeyde anksiyete deneyimledikleri saptanmıştır. Mete'nin (1998) çalışmasında kontrol grubundaki hastaların muayeneden önce durumluk anksiyete düzeyi 48.69 olarak bulunmuştur. Sonuçlarımız tüm bu çalışma sonuçları ile paralellik göstermektedir.

Çalışmamızda kadınların yaş grubunun, eğitim düzeyinin, medeni durumunun, bir işte çalışmasının, mesleğinin, başvurduğu kurumun, jinekolojik muayene sayısının, jinekolojik muayene yapan hekimin cinsiyeti, jinekolojik muayeneye gittiği, jinekolojik muayene ile ilgili hissettiği duyguların jinekolojik muayeneye bağlı anksiyetelerini etkilemediği saptanmıştır (Tablo 3). Kocabaş ve Khorshid (2012)'in çalışmasında yaş grubu, eğitim düzeyi ve deneyimlediği jinekolojik muayene sayısının, jinekolojik muayene öncesi anksiyeteyi etkilemediği saptanmıştır (Kocabaş ve Khorshid 2012). Yapılan bir çalışmada durumluk anksiyete puanlarının mesleklere ve jinekolojik muayene deneyimine göre farklılık gösterdiği bulunmuştur (Erbil, Şenkul, Sağlam ve Ergül 2008). Kocabaş ve Khorshid (2012)'ın çalışmasında, medeni durumun jinekolojik muayeneye bağılı durumluk anksiyeteyi etkilemediği bulunmuştur (Kocabaş ve Khorshid 2012). Yapılan bir çalışmada durumluk anksiyete puanlarının jinekolojik muayene deneyimine göre farklılık gösterdiği bulunmuştur (Erbil, Şenkul, Sağlam ve Ergül 2008).

Kadın hastaların jinekoljik muayene olmak için kadın hekimi tercih ettikleri şeklinde yanlış inanış vardır. Jinekolojik muayene hastanın giysilerini çıkarmasını ve özel beden bölümlerini hekim muayenesine maruz kalmasını gerektirir (Moettus, Sklar and Tanberg 1999). Jinekolojik muayeneden korkan kadınlar, jinekolojik sorunlar için bir kadın doktora muayene olmayı tercih edebilir (Larsen, Oldeide and Malterud 1997; Moettus, Sklar and Tanberg 1999; Yanıkkerem, Özdemir, Bingöl, Tatar ve Karadeniz 2007). Moettus, Sklar and Tanberg (1999) tarafından yapılan bir çalışmada, acil birimdeki hastaların erkek hekime muayene olmayı, kadın hekime muayene olmaya oranla daha sıkıntılı olarak algıladıkları, ancak daha ağrılı olarak algılamadıkları sonucuna varılmıştır (Moettus, Sklar and Tanberg 1999). Kalitatif bir çalışmada, katılımcı kadınlardan biri doktorun erkek olmasından hoşlanmayacağını, fakat diğer bir katılımcı doktorun cinsiyetini önemsemediğini belirtmiştir (Larsen, Oldeide ve Malterud 1997). Bir jinekoloji polikliniğinde 433 kadınla yapılan bir çalışmada, kadınların \%45.5'i jinekolojik izlemleri için kadın doktoru tercih edeceklerini ve \%4.2'si erkek doktor tercih edeceklerini belirtmiştir (Yanıkkerem, Özdemir, Bingöl, Tatar ve Karadeniz 2007).

Tablo 5. Kadınların Eğitim Düzeyi, Yaş Grubu Ve Bir İşte Çalışma Durumuna Göre Başvurdukları Kurumun Dağılımı

\begin{tabular}{|c|c|c|c|c|c|c|c|}
\hline & & & & Türü & & Topla & \\
\hline & Özellikler & Kamu & & Özel & & & \\
\hline & & Sayı & $\%$ & Sayı & $\%$ & Sayı & $\%$ \\
\hline Yaş & 20-30 yaş grubu & 9 & 45.0 & 11 & 55.0 & 20 & 100.0 \\
\hline Grubu & $31-40$ yaş grubu & 15 & 57.7 & 11 & 42.3 & 26 & 100.0 \\
\hline & $41-53$ yaş grubu & 6 & 42.9 & 8 & 57.1 & 14 & 100.0 \\
\hline$X=1.10$ & $S D=2, p=0.577, p<0.001$ & & & & & & \\
\hline Eğitim & İlkokul +ortaokul & 25 & 89.3 & 3 & 10.7 & 28 & 100.0 \\
\hline düzeyi & Lise & 4 & 40.0 & 6 & 60.0 & 10 & 100.0 \\
\hline & Yüksekokul & 1 & 4.5 & 21 & 95.5 & 22 & 100.0 \\
\hline$X=35.87, s$ & $D=2, p=0.000, p<0.001$ & & & & & & \\
\hline Bir işte & Çalışmayan & 25 & 78.1 & 7 & 21.9 & 32 & 100.0 \\
\hline çalışma & Çalışan & 5 & 17.9 & 23 & 82.1 & 28 & 100.0 \\
\hline$X=21.69,5$ & $D=1, p=0.000, p<0.001$ & & & & & & \\
\hline
\end{tabular}

Bir işte çalışmayan kadınların \%78.1'inin, çalışmayanların \%21.9'unun özel kamu kurumuna başvurduğu ve yapılan analizde bu farkın anlamlı olduğu saptanmıştır. Kadınların yaş grubunun, eğitim düzeyinin ve bir işte çalışmanın jinekolojik muayene için başvurduğu kuruluşu etkilediği saptanmıştır ( $p<0.001$ )(Tablo 5).

Kadınların yaş grubunun, eğitim düzeyinin ve bir işte çalışmanın jinekolojik muayene için başvurduğu kuruluşu etkilediği saptanmıştır $(p<0.001)($ Tablo 5). Daha yüksek eğitim düzeyindeki, bir işte çalışan ve daha büyük yaş grubundaki kadınlarda özel kuruma başvurma oranının daha yüksek olduğu bulunmuştur. Bu sonuç, 
kadınların gelir düzeyi ve eğitim düzeyleri arttıkça; bir işte çalışan kadınların toplumsal rollerinde artmaya paralel olarak ve kendi kararlarını bağımsız olarak verme oranının artmasına bağlanabilir.

\section{SONUÇ VE ÖNERILER}

Özel ve kamu kurumunda jinekolojik muayeneye başvuran kadınların durumluk anksiyete düzeyini karşılaştırmak amacıyla yaptığımız çalışma sonucunda;

-Kadınların yaklaşık 1/3'ü (\%28.3'ü) düzenli olarak jinekolojik muayeneye gittiklerini, diğerleri ise bir yakınması olduğunda veya gebe kaldığında jinekolojik muayeneye gittikleri,

- \%40'ı maddi yetersizlikler, iş yoğunluğu, muayene şeklinin zorluğu, muayenede kendini rahat hissetmediği veya muayeneye bağlı korku nedeniyle jinekolojik muayeneye düzenli olarak gitmediği,

- \%15'i jinekolojik muayene sırasında tedirginlik, \%13.3'ü korku, \%21.7' si utanma ve sıkıntı hissettikleri,

-1/5'i jinekolojik muayene sırasında hemşireden "nazik" (\%21.7), "güler yüzlü, bilgili, güven verici temiz" (\%20) olmasını, \%21.7'si ise jinekolojik muayene sırasında hekimden "konusunda uzman ve güvenilir" olmasını bekledikleri,

-Jinekolojik muayene sırasında orta düzeyde anksiyete deneyimledikleri,

- Yaş grubunun, eğitim düzeyinin, medeni durumunun, bir işte çalışmasının, mesleğinin, başvurduğu kurumun, jinekolojik muayene sayısının, jinekolojik muayene yapan hekimin cinsiyeti, jinekolojik muayeneye gittiği, jinekolojik muayene ile ilgili hissettiği duyguların jinekolojik muayeneye bağlı anksiyetelerini etkilemediği,

- Yaş grubunun, eğitim düzeyinin ve bir işte çalışmanın jinekolojik muayene için başvurduğu kuruluşu etkilediği saptanmıştır.

$\mathrm{Bu}$ sonuçlar doğrultusunda; jinekoloji polikliniğinde çalışan personele anksiyeteli hastaya yaklaşım konusunda hizmet içi eğitimlerin verilmesi, jinekolojik muayenenin ne olduğuna ilişkin hastaları bilgilendiren rehber formların oluşturulması önerilmektedir.

\section{KAYNAKLAR}

Aksakal SO. Jinekolojik Muayenenin Psikososyal-Medikal Yönü. T Klin Jinekol Obst 2001; 11 (2): 62-7.

Erbil N, Şenkul A, Sağlam Y, Ergül N. Jinekolojik Muayene Öncesinde Türk Kadınların Anksiyete Seviyeleri ve Muayeneye İlişkin Tutumlarının Belirlenmesi. Uluslararası İnsan Bilimleri Dergisi 2008; 5(1): 1-13.

Frye CA, Weisberg RB. Increasing The Incidence of Routine Pelvic Examinations: Behavioral Medicine's Contribution. Women Health 1994; 21 (1): 33-55.

Haar E, Halitsky V, Stricker G. Patients' Attitudes Toward Gynecological Examination and To Gynecologists. Medical Care 1977; 15 (9): 787-95.

Hilden M, K Sidenius, Langhoff-Roos J, Wijma B. Women's Experiences Of The Gynecologic Examination: Factors Associated With Discomfort. Acta Obstetricia Et Gynecologica Scandinavica 2003; 82(11): 1030-6.

Kocabaş P, Khorshid L. A Comparison of The Effects of A Special Gynaecological Garment and Music in Reducing The Anxiety Related to Gynaecological Examination. J Clin Nurs 2012; 21(5-6):791-9.

Larsen M, Oldeide CC, Malterud K. Not So Bad After All, Women's Experiences Of Pelvic Examinations. Family Practice 1997; 14(2):148-52.

McCarthy V. The First Pelvic Examination. Journal of Pediatric Health Care 1997; 11(5): 247-9.

Mete S. Jinekolojik Muayeneye Gelen Kadınlarda Oluşan Anksiyeteye Hemşirelik Yaklaşımının Etkisi. C. Ü. Hemşirelik Yüksekokulu Dergisi 1998; 2 (2): 1-8.

Millstein SG, Adler NE, Irwin CE Jr. Sources of Anxiety About Pelvic Examinations Among Adolescent Females. J Adolesc Health Care 1984; 5(2):105-11.

Moettus A, Sklar D, Tanberg D. The Effect of Physician Gender on Women's Perceived Pain and Embarrassment During Pelvic Examination. American Journal of Emergency Medicine 1999; 17(7): 635-7.

Oscarsson M, Benzein E., Wijma B. The First Pelvic Examination. Journal of Psychosomatic Obstetrics \& Gynecology 2007; 28(1): 7-12.

Öner L, LaCompte A. Durumluk Sürekli Kaygı Envanteri El Kitabı. 1. basım. İstanbul; Boğaziçi Üniversitesi Yayınevi; 1983. p. 20-6.

Reddy DM, Wasserman SA. Patient Anxiety During Gynecologic Examinations. Behavioral Indicators. The Journal of Reproductive Medicine 1997; 42(10): 631-6.

Taşkın L. Doğum ve Kadın Sağlığı Kitabı. 7.Baskı. Ankara: Sistem Ofset Matbaacılık; 2003; p. 580-1.

Yanıkkerem E, Özdemir M, Bingöl H, Tatar A, Karadeniz G. Women's Attitudes And Expectations Regarding Gynecological Examination. Midwifery 2009; 25(5): 500-8. 